\title{
Efek suplementasi $\beta$-carotene terhadap kolesterol total, trigliserida dan malondialdehid pada tikus sprague dawley yang diabet
}

\author{
Devi Ermawati ${ }^{1}$, Banundari Rachmawati ${ }^{2}$, Nyoman Suci W. ${ }^{2}$
}

\begin{abstract}
Backgrounds : diabetes mellitus (DM) is associated with increased total cholesterol and triglyceride, also well characterized by increased malondialdehyde production. $\beta$-carotene has antioxidant activity, glycemic and lipid control.

Objective : to analyze the effect of $\beta$-carotene on total cholesterol, triglyceride and MDA on diabetic Rattus norvegicus sprague dawley.

Methods : thirty rats were randomly divided into 5 groups : 1 (STZ), 2 (STZ+ $\beta$-carotene $1 \mathrm{mg} / \mathrm{kg} \mathrm{BW),} 3$ (STZ+ $\beta$-carotene 10 $\mathrm{mg} / \mathrm{kg} \mathrm{BW}$ ), 4 (STZ+ $\beta$-carotene $20 \mathrm{mg} / \mathrm{kg} \mathrm{BW),} 5$ (normal). Streptozotocin induced intraperitoneal $40 \mathrm{mg} / \mathrm{kg} \mathrm{BW.} \beta$-carotene was given by nasogastric tube on alternate days within thirty days. Blood glucose level was measured by GOD-PAP, total cholesterol by CHOD-PAP, triglyceride by GPO and MDA by ELISA with TBARS methods. Hypothesis test used one way anova then followed by post hoc bonferroni to analyze the efficient dose effect.

Results : there was a significant difference of total cholesterol ( $p=0.002)$ after $\beta$-carotene $10 \mathrm{mg} / \mathrm{kg}$ BW supplementation on alternate days within 30 days orally. $\beta$-carotene $10 \mathrm{mg} / \mathrm{kg} \mathrm{BW}$ was the most efficient dose to lowering total cholesterol. There were significant differences of triglyceride $(p=0.0001)$ and $M D A(p=0.0001)$ after $\beta$-carotene $1, \mathrm{mg} / \mathrm{kg} \mathrm{BW,10} \mathrm{mg/kg} \mathrm{BW} \mathrm{and}$ $20 \mathrm{mg} / \mathrm{kg} \mathrm{BW}$ supplementation on alternate days within 30 days orally. $\beta$-carotene $10 \mathrm{mg} / \mathrm{kg} \mathrm{BW}$ was the most efficient dose to lowering triglyceride, while $20 \mathrm{mg} / \mathrm{kg} B W$ to lowering $M D A$.

Conclusion : $\beta$-carotene $10 \mathrm{mg} / \mathrm{kg} \mathrm{BW}$ is the most efficient dose to lowering total cholesterol and triglyceride. $\beta$-carotene 20 $\mathrm{mg} / \mathrm{kg} \mathrm{BW}$ is the most efficient dose to lowering MDA.
\end{abstract}

Key words : $\beta$-carotene, total cholesterol, triglyceride, malondiadehyde, diabetic

\begin{abstract}
ABSTRAK
Latar Belakang : diabetes mellitus (DM) berkaitan dengan peningkatan kadar kolesterol total dan trigliserida, serta ditandai dengan peningktan produksi malondialdehyde. $\beta$-carotene mempunyai aktifitas antioksidan, kontrol glikemik dan kontrol lipid. Tujuan : membuktikan pengaruh pemberian $\beta$-carotene terhadap penurunan kadar kolesterol total, trigliserida dan MDA pada tikus jantan Rattus norvegicus sprague dawley diabetik.

Metode : tiga puluh ekor tikus dibagi acak menjadi 5 kelompok: 1 (stz), 2 (stz+ $\beta$-carotene $1 \mathrm{mg} / \mathrm{kg} \mathrm{BB),} 3$ (stz+ $\beta$-carotene 10 $\mathrm{mg} / \mathrm{kg} \mathrm{BB}), 4$ (stz+ $\beta$-carotene $20 \mathrm{mg} / \mathrm{kg} \mathrm{BB}), 5$ (normal). Induksi streptozotocin $40 \mathrm{mg} / \mathrm{kg} \mathrm{BB}$ intraperitoneal. $\beta$-carotene diberikan melalui sonde dua hari sekali dalam 30 hari. Pemeriksaan kadar glukosa darah dengan metode GOD-PAP, kolesterol total menggunakan CHOD-PAP, trigliserida menggunakan GPO dan MDA dengan metode TBARS. Uji hipotesis penurunan kadar kolesterol total, trigliserida dan MDA setelah perlakuan suplementasi $\beta$-carotene diuji dengan one way anova dan dilanjutkan dengan post hoc bonferroni untuk menganalisa dosis yang paling efektif dan efisien.

Hasil : terdapat perbedaan dengan bermakna pada kadar kolesterol total $(p=0,002)$ setelah pemberian $\beta$-carotene $10 \mathrm{mg} / \mathrm{kg}$ BB melalui sonde dua hari sekali dalam 30 hari. Dosis $\beta$-carotene $10 \mathrm{mg} / \mathrm{kg}$ BB yang paling efektif dan efisien untuk menurunkan kadar kolesterol total dibandingkan dosis lainnya. Terdapat perbedaan dengan bermakna pada kadar trigliserida $(p=0,0001)$ dan MDA ( $(p=0,0001)$. Dosis $\beta$-carotene $10 \mathrm{mg} / \mathrm{kg}$ BB yang paling efektif dan efisien untuk menurunkan kadar trigliserida, sedangkan dosis $\beta$-carotene $20 \mathrm{mg} / \mathrm{kg}$ BB yang paling efektif dan efisien untuk menurunkan kadar MDA dibandingkan dosis lainnya.

Simpulan : dosis $\beta$-carotene $10 \mathrm{mg} / \mathrm{kg}$ BB lebih efektif dan efisien untuk menurunkan kadar kolesterol total dan trigliserida dibandingkan dosis lainnya. Dosis $\beta$-carotene $20 \mathrm{mg} / \mathrm{kg} \mathrm{BB}$ lebih efektif dan efisien untuk mrnurunkan kadar MDA dibandingkan dosis lainnya.
\end{abstract}

Kata kunci : $\beta$-carotene, kolesterol total, trigliserida, MDA, diabetik

\section{PENDAHULUAN}

Salah satu akibat dari gangguan metabolisme pada

1 Program Studi D-IV Gizi Klinik, Jurusan Kesehatan,

Politeknik Negeri Jember, Indonesia

${ }^{2}$ Bagian Patologi Klinik Fakultas Kedokteran, Universitas Diponegoro, Indonesia diabetes mellitus yaitu hiperkolesterolemia, sehingga penderita diabetes mellitus selain memerlukan kontrol glikemik, juga memerlukan kontrol lipid darah. ${ }^{1}$ Glukosa yang berlebihan akan merusak pembuluh darah. Glukosa tidak dapat diproses menjadi energi, sehingga energi diproduksi dari sumber lain yaitu dari lemak dan protein. Akibat yang ditimbulkan dari hal 
tersebut yaitu kolesterol yang terbentuk pada rantai metabolisme lemak dan protein bertambah. Pengaturan metabolisme lipid juga dipengaruhi oleh insulin, dalam metabolisme lipoprotein di jaringan adiposa. Prevalensi hiperkolesterolemia pada diabetes mellitus yaitu $20-90 \% .^{2}$

Hiperglikemia pada diabetes mellitus menyebabkan kenaikan radikal bebas. Proses autooksidasi pada hiperglikemi memicu pembentukan radikal bebas. Radikal bebas dapat merusak membran sel, menjadi lipid peroksida atau malondialdehyde (MDA) dan dapat mengakibatkan kerusakan sistem membran sel dan kematian sel. ${ }^{3}$

$\beta$-carotene sebagai antioksidan dapat melindungi sel $\beta$-pankreas dari cytotoxicity akibat stres oksidatif yang terjadi pada diabetes mellitus. ${ }^{4}$ Suplementasi $\beta$ carotene $20 \mathrm{mg} / \mathrm{kg}$ berat badan pada tikus diabetik secara signifikan mengurangi kadar reactive oxygen species (ROS) dan meningkatkan enzim antioksidan. ${ }^{5}$ Profil lipid kelompok yang diberikan diet $\beta$-carotene $7,2 \mathrm{mg} / \mathrm{kg}$ diet lebih rendah daripada kelompok control. ${ }^{6}$ Pemberian oral $\beta$-carotene $10 \mathrm{mg} / \mathrm{kg} \mathrm{BB}$, vitamin C $10 \mathrm{mg} / \mathrm{kg} \mathrm{BB}$, vitamin E $40 \mathrm{mg} / \mathrm{kg}$ berat badan dapat meningkatkan status antioksidan dan mengurangi stres oksidatif. ${ }^{7}$ Hasil berbagai penelitian tersebut menunjukkan bahwa $\beta$-carotene mempunyai aktifitas antioksidan. Dosis $\beta$-carotene $0,3 \mathrm{mg}$ i.p secara optimal dapat memperbaiki kerusakan histologi pankreas dibandingkan dosis $0,1 \mathrm{mg}$ i.p pada tikus diabetik. $^{8}$

Tujuan dari penelitian ini yaitu untuk membuktikan dosis yang efisien dari pemberian dosis bertingkat $\beta$-carotene $1 \mathrm{mg} / \mathrm{kg} \mathrm{BB}, 10 \mathrm{mg} / \mathrm{kg} \mathrm{BB}$ dan $20 \mathrm{mg} / \mathrm{kg}$ BB melalui sonde 2 hari sekali dalam 30 hari terhadap penurunan kadar kolesterol total, trigliserida dan MDA pada tikus jantan Rattus norvegicus sprague dawley diabetik.

\section{METODE DAN BAHAN}

Rancangan penelitian yang digunakan dalam penelitian ini adalah randomized pre and post test controlled group design. Hewan percobaan yang digunakan dalam penelitian ini adalah tikus Rattus norvegicus sprague dawley jantan yang dibagi secara dalam 5 kelompok. Kelompok 1 (STZ), kelompok 2 $(\mathrm{STZ}+\beta$-carotene $1 \mathrm{mg} / \mathrm{kg} \mathrm{BB})$, kelompok $3(\mathrm{STZ}+$ $\beta$-carotene $10 \mathrm{mg} / \mathrm{kg} \mathrm{BB})$, kelompok $4(\mathrm{STZ}+\beta$ carotene $20 \mathrm{mg} / \mathrm{kg} \mathrm{BB}$ ), kelompok 5 (normal).

Hewan coba dikondisikan dalam keadaan diabetik dengan cara diinduksi STZ intraperitonial dengan dosis $40 \mathrm{mg} / \mathrm{kg}$ berat badan. ${ }^{9}$ Hewan coba dikategorikan sudah dalam keadaan diabetik apabila kadar glukosa darah > $200 \mathrm{mg} / \mathrm{dl}$. Hewan coba tikus jantan Rattus norvegicus sprague dawley berusia 8-12 minggu diperoleh dari LPPT unit 4 Universitas Gajah Mada.

Tikus dipelihara dalam kandang terpisah dengan temperatur $25 \pm 3^{\circ} \mathrm{C}$ dan tingkat kelembaban $50 \pm 5 \%$. Tikus diberikan pakan standart comfeed ADII dan minum ad libithum dengan akses bebas. Semua prosedur pemeliharaan dan perlakuan penelitian disesuaikan dengan etika penelitian hewan coba.

Tikus yang digunakan dalam penelitian ini tidak sedang mendapatkan perlakuan dari penelitian lain. Berat badan ditimbang sebagai data dasar selanjutnya dibagi secara acak menjadi 5 kelompok yaitu kelompok 1 (kelompok yang diinduksi STZ), kelompok 2 (kelompok yang diinduksi STZ 4mg/kg $\mathrm{BB}$ dan mendapatkan suplementasi $\beta$-carotene 1 $\mathrm{mg} / \mathrm{kg} \mathrm{BB}$ ), kelompok 3 (kelompok yang diinduksi STZ $40 \mathrm{mg} / \mathrm{kg}$ BB dan diberi suplementasi $\beta$-carotene $10 \mathrm{mg} / \mathrm{kg} \mathrm{BB}$ ), kelompok 4 (kelompok yang diinduksi STZ $40 \mathrm{mg} / \mathrm{kg}$ BB dan diberi suplementasi $\beta$-carotene $20 \mathrm{mg} / \mathrm{kg} \mathrm{BB}$ ) dan kelompok 5 (kelompok yang tidak diinduksi STZ dan tidak diberi suplementasi $\beta$ carotene).

Streptozotocin diberikan secara intraperitonial single dose dan pemberian suplementasi $\beta$-carotene 1 $\mathrm{mg} / \mathrm{kg} \mathrm{BB}, 10 \mathrm{mg} / \mathrm{kg}$ BB dan $20 \mathrm{mg} / \mathrm{kg}$ BB diberikan secara sonde 2 hari sekali dalam 30 hari. Pengukuran kadar kolesterol total, trigliserida dan MDA (pre test) dilakukan setelah tikus menjadi diabetik. Berat badan ditimbang setiap hari. Pengukuran kadar kolesterol total, trigliserida dan MDA (post test) dilakukan pada hari ke-31 setelah perlakuan.

\section{HASIL}

Penurunan kadar kolesterol total, trigliserida dan MDA pada tikus jantan Rattus norvegicus sprague dawley diabetik setelah diberi $\beta$-carotene dosis bertingkat $\beta$-carotene $1 \mathrm{mg} / \mathrm{kg} \mathrm{BB}, 10 \mathrm{mg} / \mathrm{kg}$ BB dan $20 \mathrm{mg} / \mathrm{kg}$ BB melalui sonde 2 hari sekali dalam 30 hari adalah sebagai berikut :

Tabel 1. Rerata kadar kolesterol total darah dan perubahannya $(\mathrm{mg} / \mathrm{dl})$

\begin{tabular}{crrrc}
\hline Kel & $\begin{array}{c}\text { Sebelum } \\
\text { Perlakuan }\end{array}$ & $\begin{array}{c}\text { Setelah } \\
\text { Perlakuan }\end{array}$ & Delta & $p$ \\
\hline 1 & $146,1 \pm 16,2$ & $149,5 \pm 15,7$ & 3,4 & 0,291 \\
2 & $146,9 \pm 5,1$ & $139,7 \pm 4,6$ & $-7,2$ & 0,016 \\
3 & $135,5 \pm 7,5$ & $114,6 \pm 6,3$ & $-20,9$ & 0,006 \\
4 & $130,1 \pm 9,9$ & $123,6 \pm 6,4$ & $-6,5$ & 0,275 \\
5 & $84,8 \pm 7,6$ & $83,9 \pm 7,8$ & $-0,9$ & 0,486 \\
\hline
\end{tabular}

Tabel 1 menunjukkan bahwa terdapat penurunan kadar kolesterol total pada kelompok 2 dan 3. 
Tabel 2. Rerata kadar trigliserida dan perubahannya $(\mathrm{mg} / \mathrm{dl})$

\begin{tabular}{crrcl}
\hline Kel & $\begin{array}{c}\text { Sebelum } \\
\text { perlakuan }\end{array}$ & $\begin{array}{c}\text { Setelah } \\
\text { perlakuan }\end{array}$ & Delta & \multicolumn{1}{c}{$p$} \\
\hline 1 & $111,2 \pm 15,2$ & $121,2 \pm 12,5$ & 10,0 & 0,234 \\
2 & $105,0 \pm 8,3$ & $72,9 \pm 10,1$ & $-32,1$ & 0,012 \\
3 & $105,8 \pm 6,7$ & $63,5 \pm 8,2$ & $-42,3$ & 0,0001 \\
4 & $114,5 \pm 8,8$ & $69,7 \pm 6,4$ & $-44,8$ & 0,0001 \\
5 & $63,0 \pm 3,2$ & $61,4 \pm 11,2$ & $-1,6$ & 0,753 \\
\hline
\end{tabular}

Tabel 2 menunjukkan bahwa terdapat penurunan kadar trigliserida pada kelompok 2, 3 dan 4 .

Tabel 3. Rerata kadar MDA dan perubahannya $(\mathrm{nmol} / \mathrm{ml})$

\begin{tabular}{ccccc}
\hline Kel & $\begin{array}{c}\text { Sebelum } \\
\text { perlakuan }\end{array}$ & $\begin{array}{c}\text { Setelah } \\
\text { perlakuan }\end{array}$ & Delta & $p$ \\
\hline 1 & $5,4 \pm 0,2$ & $5,6 \pm 0,1$ & 0,2 & 0,133 \\
2 & $5,4 \pm 0,2$ & $4,6 \pm 0,1$ & $-0,8$ & 0,009 \\
3 & $5,2 \pm 0,3$ & $4,3 \pm 0,6$ & $-0,9$ & 0,028 \\
4 & $5,1 \pm 0,1$ & $3,5 \pm 0,7$ & $-1,6$ & 0,003 \\
5 & $2,7 \pm 0,2$ & $2,6 \pm 0,1$ & $-0,1$ & 0,160 \\
\hline
\end{tabular}

Tabel 3 menunjukkan bahwa terdapat penurunan kadar MDA pada kelompok 2, 3 dan 4. Pemberian $\beta$ carotene dapat menurunkan kadar kolesterol total, trigliserida dan MDA, selanjutnya untuk menentukan dosis yang paling efisien dilakukan uji lanjutan post hoc (Tabel 4)

Hasil uji lanjutan post hoc bonferroni pada Tabel 4 menunjukkan bahwa dosis yang paling efisien untuk menurunkan kadarkolesterol total yaitu dosis $\beta$ carotene $10 \mathrm{mg} / \mathrm{kg} \mathrm{BB}$.

Tabel 4. Post hoc bonferroni multiple comparation $\beta$ carotene terhadap penurunan kadar kolesterol total antar kelompok

\begin{tabular}{cccc}
\hline $\begin{array}{c}\text { Post hoc antar } \\
\text { kelompok }\end{array}$ & $\begin{array}{c}\text { Rerata } \\
\text { penurunan }\end{array}$ & $p$ \\
\hline 1 & 2 & $-10,5$ & 0,697 \\
& 3 & $-24,2$ & 0,002 \\
2 & 4 & $-9,8$ & 0,764 \\
& 3 & $-13,6$ & 0,174 \\
3 & 4 & $-0,7$ & 1,000 \\
& 4 & $-14,3$ & 0,096 \\
\hline
\end{tabular}

p anova : 0,002
Tabel 5. Post hoc bonferroni $\beta$-carotene multiple comparation terhadap penurunan kadar trigliserida antar kelompok

\begin{tabular}{cccc}
\hline \multicolumn{2}{c}{$\begin{array}{c}\text { Post hoc antar } \\
\text { kelompok }\end{array}$} & $\begin{array}{c}\text { Rerata } \\
\text { penurunan }\end{array}$ & $p$ \\
\hline 1 & 2 & $-42,0$ & 0,0001 \\
& 3 & $-52,1$ & 0,0001 \\
2 & 4 & $-54,6$ & 0,0001 \\
& 3 & $-10,0$ & 1,0000 \\
3 & 4 & $-12,5$ & 1,0000 \\
& 4 & $-2,5$ & 1,0000 \\
\hline
\end{tabular}

p anova: 0,0001

Hasil uji lanjutan post hoc bonferroni pada Tabel 5 menunjukkan bahwa dosis yang paling efisien untuk menurunkan kadar trigliserida yaitu dosis $\beta$-carotene $10 \mathrm{mg} / \mathrm{kg} \mathrm{BB}$.

Tabel 6. Post hoc bonferroni $\beta$-carotene multiple comparation terhadap penurunan kadar MDA antar kelompok

\begin{tabular}{cccc}
\hline $\begin{array}{c}\text { Post hoc antar } \\
\text { kelompok }\end{array}$ & Rerata penurunan & $p$ \\
\hline 1 & 2 & $-0,98$ & 0,012 \\
& 3 & $-1,09$ & 0,003 \\
2 & 4 & $-1,81$ & 0,0001 \\
& 3 & $-0,10$ & 1,000 \\
3 & 4 & $-0,83$ & 0,033 \\
& 4 & $-0,72$ & 0,066 \\
\hline
\end{tabular}

p anova : 0,002

Hasil uji lanjutan post hoc bonferroni pada Tabel 6 menunjukkan bahwa dosis yang paling efisien untuk menurunkan kadar MDA yaitu dosis $\beta$-carotene 20 $\mathrm{mg} / \mathrm{kg} \mathrm{BB}$.

\section{PEMBAHASAN}

Induksi STZ pada hewan coba dapat mengakibatkan hiperglikemia, hiperlipemia dan peningkatan lipid peroksidasi. ${ }^{10}$ Hiperlipemia yang terjadi setelah injeksi STZ disebabkan karena terjadi peningkatan absorbsi lipid di usus, perubahan peningkatan (abnormal) aktivitas a-cholesterol acyltransferase (ACAT) di usus kecil. Kekurangan atau defisiensi insulin mengakibatkan metabolisme asam lemak yang berlebihan. Peningkatan kadar asam lemak bebas akan meningkatkan sekresi very low density lipoprotein (VLDL) yang disertai dengan trigliserid dan kolesterol. ${ }^{11}$

Peningkatan kadar glukosa darah dan kolesterol total pada kondisi diabetik akan mengakibatkan lipotoxic (lipotoksisitas) yang mengakibatkan akumulasi lipid dalam sel beta sehingga dapat 
memicu apoptosis sel beta. Long chain acyl-CoA intraseluler dapat mengaktivasi isoform PKC yang dapat mengakibatkan fosforilasi serine/threonine pada molekul insulin receptor substrate (IRS) di dalam sel beta, memicu degradasi IRS-2 dan mengakibatkan apoptosis sel beta. ${ }^{12}$

Keadaan hiperglikemia akan memicu terjadinya radikal bebas dan peroksidasi lipid. Hal ini dikarenakan oleh radikal bebas bereaksi dengan poliunsaturated fatty acid (PUFA), dimana PUFA memiliki ikatan rangkap berganda diantara methylene bridges $\left(\mathrm{CH}_{2}-\right) .{ }^{13}$ Hiperglikemia yang berkepanjangan pada diabetes mellitus akan memicu penumpukan radikal bebas yang bersifat toksik. Mekanisme terbentuknya radikal bebas yang diakibat oleh hiperglikemia antara lain melalui jalur AGEs, poliol, PKC, hexosamine dan ROS. ${ }^{14}$

Radikal bebas yang dihasilkan dapat menyebabkan kerusakan seluruh membran biologis dengan cara merusak protein, lipid, asam nukleat, dan glikokonjugat. Peroksidasi lipid merupakan proses oksidasi asam lipid tidak jenuh berantai panjang PUFA pada membran sel yang menghasilkan radikal peroksida, hidroperoksida dan produk aldehida seperti MDA. Oleh karena itu kadar MDA dapat digunakan sebagai salah satu parameter mengukur peroksidasi lipid dan kerusakan oksidatif. $^{7}$

Pemberian $\beta$-carotene dapat menekan lipid peroxide, sehingga lipotoxic dapat dicegah dan keadaan dislipidemia dapat dikontrol. ${ }^{15}$ Diabetes mellitus berkaitan dengan kelainan metabolisme lipid. Hiperlipemia pada diabetes mellitus tergantung pada lamanya kekurangan insulin, resistensi insulin, obesitas, diit dan penyebab lain dari hiperlipemia. Diabetes mellitus dengan hiperlipemia dan ketidaknormalan lipoprotein berasal dari interaksi stres oksidatif dan radikal bebas yang mengarah pada peningkatan peroksidasi lipid dalam plasma, jaringan dan membran, sehingga menyebabkan kerusakan jaringan. Peroksidasi lipid secara kronis mengakibatkan penumpukan radikal bebas yang dapat mengakibatkan etiopatogenesis dan komplikasi pada diabetes mellitus. ${ }^{16}$

$\beta$-Carotene selain dapat digunakan sebagai kontrol glikemik juga dapat digunakan sebagai kontrol lipid. ${ }^{6}$ $\beta$-Carotene sebagai antioksidan dapat menghambat oksidasi lipoprotein sehingga komplikasi dan kerusakan sel akibat hiperglikemia dapat dihindari. ${ }^{17}$

Insulin dapat mempengaruhi pengaturan metabolisme lipid yaitu pada metabolisme lipoprotein di jaringan adipose. Insulin menghambat lipolisis dan mengaktifkan lipoprotein lipase sehingga dapat meningkatkan katabolisme lipoprotein kaya trygliceride dalam menghambat produksi very low density lipoprotein (VLDL). Insulin meningkatkan clearance low density lipoprotein (LDL) dengan cara merangsang aktifitas reseptor Apo B/E (reseptor LDL) dan meningkatkan degradasi LDL. Insulin juga berperan pada metabolisme high density lipoprotein (HDL) dengan cara mengaktifkan lecithin-cholesterol acyltranse (LCAT) dan meningkatkan aktivitas lipase di hepar. Insulin memicu lipogenesis dengan cara meningkatkan transport glukosa ke dalam sel sehingga mengakibatkan peningkatan ketersediaan piruvat untuk sintesis asam lemak dan gliserol. ${ }^{18}$

$\beta$-carotene mempunyai efek glikemik yang dapat digunakan sebagai kontrol glikemik dan trigliserida. Proses penyerapan lemak terjadi di usus halus oleh membran sel. Lemak yang diserap di usus halus akan mengalami esterifikasi membentuk kilomikron. Kilomikron selanjutnya akan dilepaskan ke dalam sirkulasi darah melalui saluran limfe. Metabolisme lipid pada jaringan adiposa meliputi proses lipogenesis (sintesis lipid) pada jaringan adiposa, triasilgliserol disuplai dari hati dan usus dalam bentuk lipoprotein, VLDL dan kilomikron. ${ }^{19}$

Asam lemak dari lipoprotein dilepaskan oleh lipoprotein lipase yang berlokasi pada permukaan selsel endotelial pembuluh kapiler darah. Asam lemak kemudian diubah menjadi triasilgliserol. Oleh karena itu dengan pemberian $\beta$-Carotene dapat membantu memperbaiki kontrol glikemik dan respon insulin untuk menurunkan kadar trigliserida pada keadaan diabetik. ${ }^{20}$

$\beta$-Carotene mempunyai aktifitas sebagai anti oksidan yang dapat mengontrol radikal bebas dengan cara menangkap singlet oxygen $\left({ }^{1} \mathrm{O}_{2}\right)$ dan mengimbangi produksi radikal peroksida. Hasil dari reaksi $\beta$-carotene menangkap radikal bebas yaitu oksigen dan triplet exitasi karotenoid. ${ }^{21}$

$\beta$-carotene dapat meningkatkan status anti oksidan pada penderita diabetes mellitus tipe-2. $\beta$-carotene bersifat antioksidan dan dapat mengimbangi penumpukan radikal bebas pada keadaan hiperglikemia atau diabetes mellitus. Hiperglikemia dalam jangka panjang akan menyebabkan peningkatan produksi radikal bebas dari glukosa, glikosilasi autooksidasi dan protein. Peningkatan dan penumpukan radikal bebas akan mengurangi status antioksidan endogen, sehingga dengan pemberian $\beta$-carotene sebagai antioksidan eksogen dapat meningkatkan status antioksidan dalam tubuh untuk menghambat produksi radikal bebas yang berlebihan. Pemberian antioksidan pada diabetes mellitus juga mempunyai fungsi agar tidak terjadi komplikasi lebih lanjut. ${ }^{22}$

Dosis $10 \mathrm{mg} / \mathrm{kg}$ BB pada tikus dikonversikan ke dosis manusia, setara dengan $1,6 \mathrm{mg} / \mathrm{kg} \mathrm{BB}$ pada manusia. Aplikasi dosis $\beta$-carotene pada manusia 
dengan berat badan $50 \mathrm{~kg}$ membutuhkan $80 \mathrm{mg} \beta$ carotene. Kebutuhan $80 \mathrm{mg} \quad \beta$-carotene bisa didapatkan dari kandungan $\beta$-carotene pada $1 \mathrm{~kg}$ wortel untuk 2 hari sekali.

\section{SIMPULAN}

Dosis $\beta$-carotene $10 \mathrm{mg} / \mathrm{kg} \mathrm{BB}$ adalah dosis yang paling efisien untuk menurunkan kolesterol total dan trigliserida. Dosis yang paling efisien untuk menurunkan kadar MDA yaitu dosis $\beta$-carotene 20 $\mathrm{mg} / \mathrm{kg} \mathrm{BB}$.

\section{DAFTAR PUSTAKA}

1. American Diabetes Association (ADA). 2011. Standart of Medical Care of Diabetes : Medical Nutrition Therapy

2. Johansen JS, Harris AK, Rhycly D., Ergul A. Oxidative Stress and The Use of Antioxidant in Diabetes : Linking Basic Science to Clinical Practise. Cardiovascular Diabetology 2005;4 (5) : 1-11

3. Hanachi P, Rashid Haidari M., Lattifah A.L. Investigation of Lipid Profiles and Lipid Peroxidation in Patients with Type 2 Diabetes. European Journal of Scientific Research 2009; 28 (1): 6-12

4. Furusho, T., E. Kataoka, T. Yasuhara, M. Wada and S. Innami. Administration of Beta-Carotene Suppresses Lipid Peroxidation in Tissues and Improves The Glucose Tolerance Ability of Streptozotocin-induced Diabetic Rats. Int Journal Vitamin Nature Res 2002; 72: 71-76

5. Thyagaraju BM, Shrilata B, Muralidhara. Oral Supplementation of $\beta$-Carotene Significantly Ameliorates Testicular Oxidative Stress in The Streptozotocin-Diabetic Rat. International Journal of Fertility and Sterility 2008; 2(2):74-81

6. Seo JS, Lee KS, Jang JH, Quan Z, Kyung MY Yang M, Burri BJ. The Effect of Dietary Supplementation of $\beta$-carotene on Lipid Metabolism in STZ Induced Diabetic Rats. Nutrition Research. 2004; 24: 1011-21

7. Sharma M, Katyal T, Grewal G, Behera D, Budhiraja RD. Effect of Antioxidants such as $\beta$ carotene, vitamin $\mathrm{C}$ and vitamin $\mathrm{E}$ on Oxidative Stress, Thermal Hyperalgesia and Cold Allodynia in STZ Induced Diabetic Rats. Journal of Pharmacology. 2009; 6 (2)

8. Attia A. Histologi and Electrone Microscopic Studies of The Effect of $\beta$ Carotene on The
Pancreas of Streptozotocin (STZ) Induced Diabetic Rats. Pakistan Journal of Biological Sciences. 2009;12 (4) : 301-14

9. Banundari R. Pengaruh pemberian folat terhadap kadar homosistein, Nitric Oxyde dan status retinopati diabetik (studi ekperimental pada tikus Sprague Dawley). Disertasi Program Doktor Universitas Diponegoro Semarang. 2012.

10. Dhirgo, A. Hubungan konsentrasi malondialdehida, glukosa dan kolesterol pada tikus putih yang diinjeksi dengan streptozotocin. Journal Sain Veteriner. 2008; Vol.26 No.2

11. Vander Geer P, Wiley S, Pawson T. Reenginering The Target Specificity of The Insulin Receptor by Modification of a PTB Domain Binding Site. Oncogene. 1999; 18 (20) : 3071-5

12. Trivedi NA, Mazumder, B., Shatt, JD., Hemavathi, KG. Effect of Shilajit on Blood Glucose and Lipid Profile in Alloxan-induced Diabetic Rats. Indian J Pharmacol. 2004; 36(6) : 373-6

13. Muller, F.L., Lustgarten, M.S., Jang Y., Richardson, A, Van Remmen H. Trends in Oxidative Agging Theories. Free Radic Biol Med. 2007; 43: 477-503

14. Romeo GR, Lee J, Shoelson SE. Metabolic Syndrome, Insulin Resistance and Roles of Inflammation : Mechanisms and Therapeutic Targets. Arterioscler Thromb Vasc Biol. 2012; $32(8): 177-83$

15. Silva PS, Cavallerano JD, Sun JK, Lloyd M. Aiello LM, Aiello LP. Diabetic Retinopathy: Effect of Medications on Onset and Progression: Agents for Lipid Control. Faculty and Disclosures CME. 2011.

16. Andallu B, Kumar AVV, Varadacharyulu N Ch. Lipid Abnormalities in Streptozotocin-Diabetes : Ameliorates by Morus indica L. Cv Suguna leaves. Int Journal Diabetes Dev Ctries. 2009;29 (3) : 123-28

17. Ali M, Al Shamma G, Hashim H. Beta Carotene, Glycemic Control and Dyslipidemia in Type 2 Diabetes Mellitus. Journal Faculty Medicine Baghdad. 2006; 48:435-41

18. Verges B. Insulin sensitivity and Lipids. Diabetes Metab. 2001; (27) : 223-7

19. Ahmed et al. BMC Complementary and Alternative Medicine. Biomedcentral. 2013; 13: 10

20. Guyton AC and Hall JE. Textbook of Medical Physiology $11^{\text {th }}$ ed. Philadelphia-PA-USA. 2006. 
21. Stahl W, Sies H. Antioxidant Activity of Carotenoids. Molecular Aspects of Medicine 2003; $24: 345-51$

22. Levy Y, Zaltberg H, Ben-Amots A, Kanter Y, Aviram M. Beta Carotene Affects Antioxidant Status in Non-insulin dependent diabetes mellitus. Pathophysiology. 1999; 6 : 157-61 